\title{
Research Article: Evaluation of rice pre-breeding lines for gall midge resistance
}

Article Chronicle:

Received :

15.07.2017;

Accepted :

30.07.2017

\section{KEY Words :}

Gall midge, Prebreeding lines, Resistance

\section{CH. ANUSHA, A.P PADMAKUMARI,T. UMA MAHESWARI, S. MALATHI, S. OM PRAKASH AND CH. DAMODAR RAJU}

SUMMARY : Pre-breeding lines with known source of gall midge resistance through $\mathrm{Gml}$ gene in the elite backgrounds were evaluated in a replicated trial under greenhouse conditions at IIRR, Rajendranagar, Hyderabad against biotype 1 and in field at Jagtial and Warangal against biotype 3 and 4, respectively. Screening of 15 day old seedlings of the test lines against gall midge biotype 1 was carried out by releasing gall midge adults. Field screening for biotype 3 and $4 \mathrm{M}$ was carried out under natural infestation in endemic areas. Scoring for damage was done when at least $50 \%$ of the susceptible check plants exhibited damage symptoms as silver shoots. Data on total number of plants and number of plants with silver shoots were taken. Per cent plant damage and silver shoots was calculated. Among 38 prebreeding lines, chosen with phenotypic acceptability, 12 lines showed nil damage from four crosses against biotype 1 and 6 lines against biotype 3. Of these RNR17927-1 (Tellahamsa X JGL11690) andRNR19872, RNR19875, RNR19880, RNR19881 and RNR19883(MTU1010/JGL3855) were found resistant against both biotype 1 and 3 but susceptible to biotype $4 \mathrm{M}$.

How to cite this article : Anusha, Ch., Padmakumari, A.P., Maheswari, T. Uma, Malathi, S., Prakash, S. Om and Raju, Ch. Damodar (2017). Evaluation of rice pre-breeding lines for gall midge resistance. Agric. Update, 12(TECHSEAR-5) : 1300-1307; DOI: 10.15740/HAS/AU/12.TECHSEAR(5)2017/1300-1307.
Author for correspondence :

\section{A.P. PADMAKUMARI}

ICAR-Indian Institute of Rice Research,

Rajendranagar, HYDERABAD (TELANGANA) INDIA

Email :

padmakumariento@

gmail.com

See end of the article for

authors' affiliations 